\title{
Culture Proven Bacterial Meningitis in Children: Agents, Clinical Profile and Outcome
}

\author{
Ansari I, Pokhrel Y
}

Department of Pediatrics

Patan Academy of Health Sciences, Patan Hospital

Lagankhel, Lalitpur; Nepal

\section{Corresponding Author \\ Dr Imran Ansari \\ Department of Pediatrics \\ Patan Hospital, Lagankhel, Lalitpur; \\ E-mail: imranansari@pahs.edu.np}

Citation

Ansari I, Pokhrel Y. Culture proven bacterial meningitis in children - agents, clinical profile and outcome. Kathmandu Univ med J 2011;33(1)36-40.

\begin{abstract}
Background

Meningitis is a serious infection. Little is known about the bacterial agents and their antibacterial sensitivity in Nepalese children.
\end{abstract}

\section{Objectives}

To study bacteriological agents, clinical profile and immediate outcome in patients admitted to children's ward of Patan Hospital with meningitis.

\section{Methods}

Prospective observational study conducted in paediatric ward of Patan Hospital. All the children admitted to the ward, with the diagnosis of culture proven bacterial meningitis' on discharge were eligible.

\section{Results}

Out of 7,751 children, 296 (3.8\%) had meningitis. This was a group ranging from neonates to adolescents aged 18 years. Only $13(4.4 \%)$ of cerebrospinal fluid samples taken from them yielded positive culture reports. The organisms were pneumococcus (6), Haemophilus influenza ' $b$ ' (3), $\beta$-hemolytic Streptococcus (1), $\alpha$-hemolytic Streptococcus (1), N. meningitides (1) and Pseudomonas (1). Whereas Haemophilus influenza ' $b$ ' was isolated from young infants, pneumococci were found in the young as well as the old. Fever, vomiting, high leukocyte count with left shift were all commonly present. All but one had cerebrospinal fluid pleocytosis. Low sugar and high protein was found in most specimens. Neuroimaging was done in six children of which three were abnormal (all young infants and pneumococci cases). Ceftriaxone was given to all but one child. Everybody recovered but three had complications - profound hearing loss and cortical atrophy with subdural collection in pneumococcal and septic arthritis with persistence of fever in Haemophilus influenzae ' $b$ ' meningitis.

\section{Conclusion}

The present study corroborates most of the epidemiological and clinical features of acute bacterial meningitis and sheds light on the causative agents of bacterial meningitis in Nepalese children.

\section{KEY WORDS}

antibiotics, CSF, meningitis, pneumococcus

\section{INTRODUCTION}

Meningitis is one of the most severe infections in children. Despite the availability of newer antibiotics and preventive strategies, morbidity and mortality due to bacterial meningitis has not changed much in the past two decades. ${ }^{1}$ To be able to diagnose and manage properly, paediatricians have to be aware of the types of micro-organisms prevalent in the local community and their susceptibility against different antibiotics. What is true in the western world may not be so in our part of the world. There is paucity of objective data on the causative agents and their susceptibility in Nepalese population. The current study was undertaken to fill this gap in information. 


\section{METHODS}

This was a prospective study carried out in the children's ward of Patan Hospital. This hospital is collaborating with Oxford University and New Zealand University to find bacterial causes of febrile illnesses in Nepalese children. The present study is a part of the findings of that project.

The presented data were collected between Mangsir 2062 and Magh 2065. All the children admitted in the children ward of Patan Hospital were eligible for study. They were followed everyday by the research team till discharge. blood and cerebrospinal fluid culture were traced and recorded. Final diagnosis, made by the treating team of physicians, was also entered into the individual sheets.

Later, all the sheets with positive CSF culture for bacterial meningitis were collected and time interval between the first and the last case noted. The total number of patients admitted during this period as well as all those with discharge diagnosis of 'meningitis' were entered for analysis. All the files of the subjects with positive CSF culture were retrieved from the record section of the hospital and studied in detail.

\section{RESULTS}

A total of 7,751 patients were admitted in the paediatric ward during the 38 months of study. Of them, 296 were treated for meningitis. Only in 13 out of the 296 patients, an organism was grown in the CSF. Pneumococcus was the most common bacteria isolated followed by Haemophilus influenzae ' $b$ ' (Hib)., ${ }^{2,3}$ There was one each of $\beta$-hemolytic Streptococcus, $\alpha$-hemolytic Streptococcus, Pseudomonas and Neisseria meningitidis. In samples from five of the six patients with pneumococcal meningitis, the same organism was grown from blood samples as well. Similarly, two of three Hib meningitis patients also had positive blood culture for the same bacteria.

The mean age of patients was 3.5 years. Infants as young as 18 days old to adolescents of up to 13 years were affected (Table 1). Six out of 13 patients were young infants. Hib meningitis was seen in young children only: mean age 8 months, oldest child 17 months. But pneumococci were grown from samples from all the children. There was no gender influence as seven males and six females were affected.

Fever was the most common presentation, with all but one child suffering from it. As shown in the bar diagram below (Figure 1) vomiting was also quite common (10; 77\%). Symptoms more specific to CNS, namely, seizures and impairment of consciousness were present in five and two patients respectively. Three children had generalized seizure and two had partial. Four patients complained of headache.

A majority of children (nine; 69\%) had more than 11,000 / $\mathrm{mm}^{3}$ peripheral WBC count, the highest being $27,200 / \mathrm{mm}^{3}$.
The number of children with a count of more than 15,000/ $\mathrm{mm}^{3}$ was five as shown in Table II. The WBC count was more than $17,000 / \mathrm{mm}^{3}$ in all but one child. On the other hand no Hib case had a total count of more than 13,000/ $\mathrm{mm}^{3}$ (maximum $12400 / \mathrm{mm}^{3}$, minimum $7900 / \mathrm{mm}^{3}$ ).

In all 13 children there was predominance of neutrophil in their peripheral blood. The percentage ranged from 58\% - 96\%. Five patients had 58\%-75\%, two had $75 \%-80 \%$ and the remaining six had a very significant left shift of more than $80 \%$ neutrophil.

Of the groups of individual organisms, pneumococci had closest association with leukocytosis and neutrophilia. Four out of the six pneumococci affected children showed leukocytosis as well as neutrophilia (WBC>15,000/ $\mathrm{mm}^{3}$; Neutrophil $\geq 80 \%$ ). Of the remaining two, one had leukocytosis without much left shift (WBC >15,000/ $\mathrm{mm}^{3}$; Neutrohil <80\%). The last one exhibited neither significant leukocytosis nor neutrophilia (WBC <15,000/ $\mathrm{mm}^{3}$; Neutrophil <80\%). As noted earlier, none of the three Hib children had a white count in excess of $15,000 / \mathrm{mm}^{3}$. Two of them, however, had neutrophilia of $>80 \%$. The last Hib child, as in the case of one child with pneumococcal meningitis, had normal total as well as differential white cell count $\left(<15,000 / \mathrm{mm}^{3} ;<80 \%\right)$.

CSF pleocytosis was found to be variable. Seven children showed significant CSF pleocytosis of more than 1,000 cells $/ \mathrm{mm}^{3}$. The highest count $\left(67,500 / \mathrm{mm}^{3}\right)$ was found in a three months old female child who grew Hib in her CSF. Of the remaining six, three patients had CSF cells in the range of $100 / \mathrm{mm}^{3}-1000 / \mathrm{mm}^{3}$. Three children had fewer than $100 \mathrm{WBC} / \mathrm{mm}^{3}$. The least number of cells was two $/ \mathrm{mm}^{3}$. This was an 18 month old girl with $\alpha$-hemolytic streptococcal meningitis. As shown in the table 2, there was no correlation between blood and CSF white cell count.

CSF sugar was significantly decreased (less than $20 \mathrm{mg} \%$ ) in 10 patients and protein significantly increased (more than $45 \mathrm{mg} \%$ ) in 11. Both low sugar and high protein was found in four (out of six) pneumococcal infections, all three $\mathrm{H}$. influenzae infections and one each of Pseudomonas and $\beta$-hemolytic Streptococcus infections.

All pneumococcal as well as the $\alpha$ - and $\beta$-hemolytic Streptococcus and Neisseria meningitides bacteria were uniformly sensitive to the three commonly used antibiotics - penicillin, cefotaxime and chloramphenicol. The Haemophilus and Pseudomonas had variable sensitivities against these antibiotics as shown in Table III.

All but one children received ceftriaxone/ cefotaxime. Four of them were also given chloramphenicol. The lone child who was not put on ceftriaxone was an 18 month old female. Her CSF showed only two cells, meningitis was not considered initially and hence she was put on ampicillin. Later the CSF culture showed $\alpha$-hemolytic Streptococcus sensitive to penicillin, chloramphenicol and cefotaxime. Ampicillin was stopped and a full course of crystalline penicillin was given. She responded well to the treatment. 


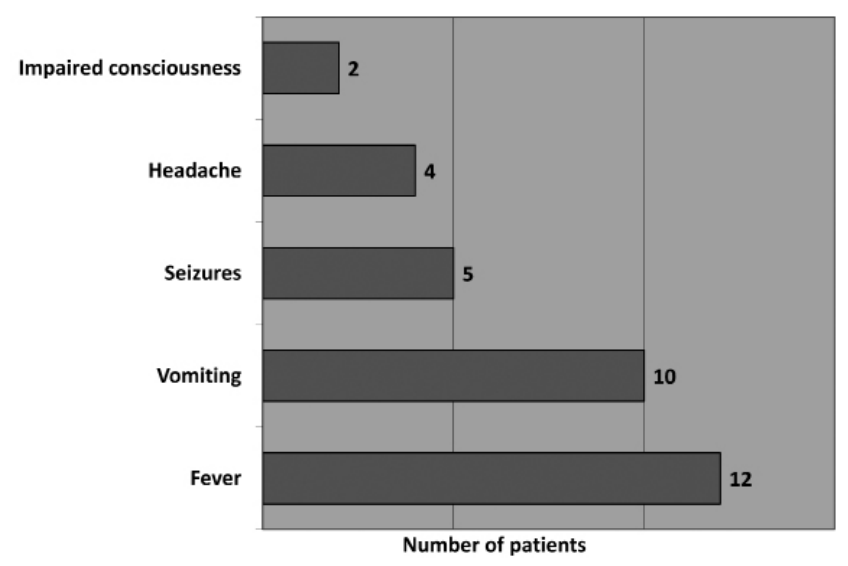

Figure 1. Presenting symptoms of the studied patients

Table 1. Age wise distribution of meningitis caused by different bacteria

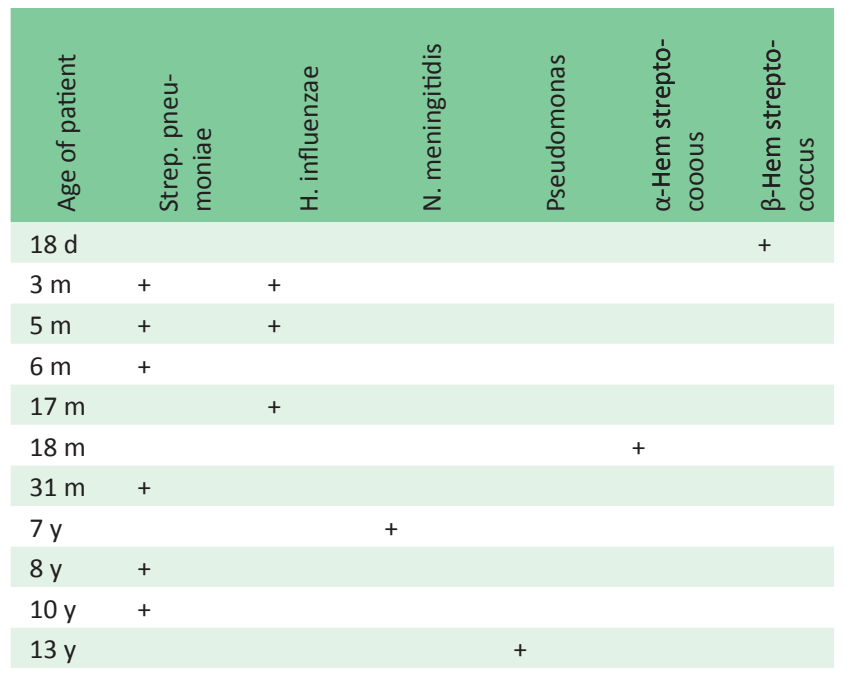

Table 2. Peripheral blood response and CSF pleocytosis

\begin{tabular}{|c|c|c|c|c|}
\hline Age & $\begin{array}{l}\text { Peripheral } \\
\mathrm{WBC} / \mathrm{mm}^{3}\end{array}$ & $\begin{array}{l}\text { Neutro- } \\
\text { phil } \\
\text { (\%) }\end{array}$ & $\mathrm{CSF} \mathrm{WBC} / \mathrm{mm}^{3}$ & Organism in CSF \\
\hline $5 \mathrm{~m}$ & 5,900 & 80 & 310 & S. pneumonia \\
\hline $17 \mathrm{~m}$ & 7,900 & 77 & 1,300 & $\mathrm{Hib}$ \\
\hline $7 y$ & 8,800 & 96 & 1,300 & N. meningitides \\
\hline $3 \mathrm{~m}$ & 8,900 & 70 & 67,500 & $\mathrm{Hib}$ \\
\hline $5 \mathrm{~m}$ & 12,400 & 95 & 6,400 & $\mathrm{Hib}$ \\
\hline $18 \mathrm{~d}$ & 13,000 & 64 & 1,780 & $\beta$-hem strep \\
\hline $8 y$ & 13,400 & 84 & 28 & S. pneumonia \\
\hline $13 y$ & 15,000 & 74 & 276 & Pseudomonas \\
\hline $18 \mathrm{~m}$ & 15,700 & 82 & 2 & $\alpha$-hem strep \\
\hline $6 \mathrm{~m}$ & 17,500 & 58 & 9,800 & S. peumoniae \\
\hline $31 \mathrm{~m}$ & 18,200 & 87 & 780 & S. pneumonia \\
\hline $10 y$ & 19,600 & 61 & 4,000 & S. pneumonia \\
\hline $3 \mathrm{~m}$ & 27,200 & 84 & 60 & S. pneumonia \\
\hline
\end{tabular}

Once treatment was started, fever came down to normal within four days in others but in those with pneumococcal infection, it took six days for temperature to normalize. The average number of days taken for defeverescence in those with Hib meningitis was 13.

Repeat CSF study was done in four complicated cases. The result is shown in Table IV. In the two children with Hib meningitis it was repeated twice (altogether three spinal taps). The results of repeat CSF study showed improvement in all parameters. Thus in the first case the CSF WBC count came down from $6,400 / \mathrm{mm}^{3}$ to $16 / \mathrm{mm}^{3}$. When the CSF was done for the third time it became completely normal (1). An exception was the case of pneumococcus where, although CSF sugar increased from seven $\mathrm{mg} \%$ to $33 \mathrm{mg} \%$ and WBC decreased from $310 / \mathrm{mm}^{3}$ to $80 / \mathrm{mm}^{3}$, protein actually increased (instead of decreasing) from $82 \mathrm{mg} \%$ to $152 \mathrm{mg} \%$. None of the repeat CSF samples grew any organisms.

Neuro-imaging was performed in six of the 13 patients - four cranial USGs and two CT scans. Three USGs were normal. The fourth one showed abnormally prominent echogenic sulci and gyri suggestive of meningitis. One of the CT scans showed subdural collection with cortical atrophy. This was a three month old child with pneumococcal meningitis. The subdural fluid was tapped. Pneumococcus was isolated from this specimen also.

Ten of the 13 children had complete recovery without any sequel. Three recovered but with some complications. The complications were: (1) bilateral profound hearing loss, (2) subdural collection requiring neurosurgery with repeated meningitis, and (3) septic arthritis with persistent fever. These complications were noted before discharge from hospital. The first two complications were observed in pneumococcal meningitis patients and the last one in Haemophilus. There was no death in this series.

\section{DISCUSSION}

In our study 296 children were clinically diagnosed to have meningitis which gives a hospital based prevalence of $3.8 \%$. Out of the 296 CSF samples of these children, 13 grew some bacteria. Thus the bacterial yield was only $4.4 \%$. Elerie J. Williams et al also could recover only 9 bacteria from culture of 199 CSF samples (yield 4.5\%). ${ }^{2}$ There are two possible explanations for this low yield: (1) Some of the cases were not bacterial meningitis in the first place; they were probably viral meningitis but because of the borderline CSF picture, got labeled and treated as bacterial meningitis, or (2) the subjects were already on antibiotics when CSF was examined. Several studies have shown lower yield because of prior use of antibiotics. ${ }^{3}$

Pneumococci were the most common organisms isolated: $46 \%$ of the cases. This finding is similar to that of other researchers in this country as well as those of the USA and Europe. ${ }^{2,4,5}$ Kaplan SL and colleagues found that even after the introduction of pneumococcal conjugate vaccine in the 
immunization program in 2000, pneumococcus remains the commonest bacteria causing meningitis in children in the US, albeit with a much lower attack rate. ${ }^{6}$

$H$. influenzae ' $b$ ' was isolated in $23 \%$ of children in our study. A study done in the USA in 1986, before Hib vaccine was introduced in the routine immunization schedule, found $H$. influenzae to be the most common cause of bacterial meningitis (45\%). ${ }^{7}$ By this corollary one would expect Hib to be the number one in our study also because this study is like the pre-Hib-vaccine era of the USA (Hib was included in Nepal EPI in Mansir 2066 whereas the present study concluded one year earlier). ${ }^{8}$ But that was not the case.

In five of the six patients with pneumococcal meningitis, the same organism was also grown in their blood samples. Similarly, two of three Hib meningitis patients also had positive blood culture for the same bacteria. Medical literature suggests that more than $50 \%$ of meningitis patients have positive blood cultures for the causative bacteria. ${ }^{9}$

Most patients (46\%) were young infants of six months or less. A study in the USA before widespread use of Hib vaccine also found meningitis to be predominantly a disease of young infants. ${ }^{10}$ In our study, Hib meningitis was seen in young children but pneumococcus did not spare any age group. It is a well known fact that Haemophilus influenzae is a disease of under-five children. ${ }^{11}$

Fever, vomiting and seizures were the most common presenting complaints. This finding was in accordance with what is generally expected..$^{12}$ Only four children complained of headache but this may have been because of age since children less than two years cannot tell and we had seven patients below this age. Leukocytosis in the peripheral blood was common (69\%) and neutrophilia universal (100\%). Particularly high count of $\geq 15,000 / \mathrm{mm}^{3}$ cells and significant neutrophilia of $\geq 80 \%$ was a distinguishing feature of peumococcal meningitis (four out of six; $67 \%$ ) which goes well with established medical knowlwdge. ${ }^{13}$

All pneumococci were uniformly sensitive to the three commonly used antibiotics - penicillin, cefotaxime and chloramphenicol. Suvana Karki, in her study in Kanti Children's Hospital Kathmandu, also found $100 \%$ sensitivity of pneumococci to penicillin and chloramphenicol. ${ }^{14}$ This is reassuring because the West is facing a worrying trend of more and more pneumococci becoming resistant not only to penicillin but also to third generation cephalosporins. In one study in the USA in 1998, researchers found as many as $20 \%$ of pneumococcus resistant to penicillin and $7 \%$ resistant to cefotaxime. ${ }^{15}$

In our study ceftriaxone/cefotaxime was given to all but one child. Four of them also received chloramphenicol. The lone child who was not put on ceftriaxone was treated with ampicillin/penicillin since meningitis was not considered initially because of normal CSF cytology. This supports the statement that in some cases of bacterial meningitis 'early in the course, few or no WBCs may be present'. ${ }^{16}$
Table3. Culture sensitivity of the different bacterial isolates

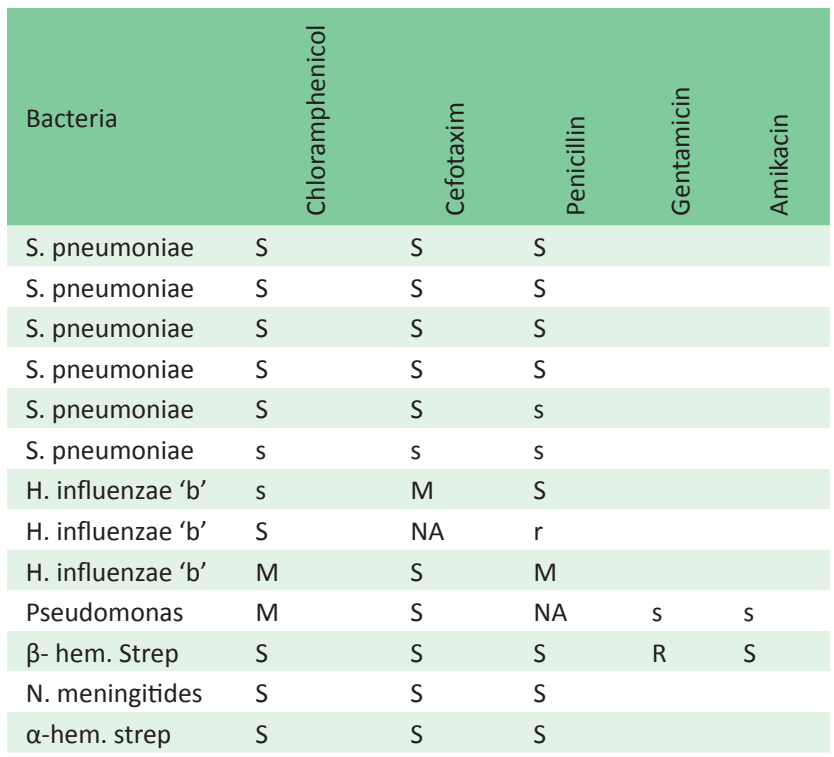

$S=$ Sensitive, $M=$ Moderately sensitive, $R=$ Resistant, $N A=$ Not available

Table 4. Repeat CSF study

$\begin{array}{llll}\text { Bacteria } & \text { WBC } / \mathrm{mm}^{3} & \text { Protein }(\mathrm{mg} \%) & \text { Sugar }(\mathrm{mg} \%) \\ \text { Hib } & 16,1 & 97,20 & 31,49 \\ & {[6400]} & {[300]} & {[2]} \\ \text { Hib } & 370,113 & 68,176 & 28,41 \\ & {[67500]} & {[652]} & {[15]} \\ \text { Pseudomonas } & 25 & 48 & 43 \\ & {[276]} & {[76]} & {[6]} \\ \text { S. pneumoniae } & 80 & 152 & 33 \\ & {[310]} & {[82]} & {[7]}\end{array}$

The figures in parentheses are the result of initial CSF study The two numbers separated by a coma above parentheses are the results of two repeats.

In children with pneumococcus meningitis, it took six days for normalization of temperature after initiation of therapy. Klein J, as well as Arditi $M$, in their respective studies, also found disappearance of fever within four to six days after starting antibiotic treatment. ${ }^{16,17}$ Children with Hib meningitis, on the other hand, took longer for the disappearance of fever - 13 days on an average. Other researchers have also found that as many as $13 \%$ of children with meningitis may take 10 days or longer for the temperature to become normal. ${ }^{18}$

Repeat CSF study was done in four complicated cases. Tunkel AR et al. advise that repeat CSF examination be done in those with poor clinical response. ${ }^{19}$ In the two children with Hib meningitis it was repeated twice. The results of repeat CSF study showed improvement in all parameters except for one case of pneumococcus, where CSF protein actually increased, instead of decreasing. None of the repeat CSF samples grew any organism. 
Three complications were observed in our study (23\%) which is similar to the findings of a meta-analysis for developing countries (26\%). ${ }^{20}$ The complications were: (1) bilateral profound hearing loss, (2) subdural collection with repeated meningitis, and (3) septic arthritis with persistent fever. In the above mentioned meta-analysis also, hearing loss was the most common complication (20.6\%). The first two complications in our study were observed in pneumococcal meningitis patients and the last one in haemophilus. There was no death in this series although a mortality rate of $5-10 \%$ can be expected in cases of bacterial meningitis. ${ }^{1}$

\section{CONCLUSION}

The present study corroborates most of the epidemiological and clinical features of acute bacterial meningitis presently known to the medical fraternity. It further proves that lack of CSF pleocytosis, particularly in the first few days of the disease, can be deceptive and hence should be regarded very suspiciously taking into account the whole clinical picture before deciding not to treat the disease as meningitis. The belief that pneumococci, in our part of the world, are uniformly sensitive to penicillin and third generation cephalosporin, was found to be true.

The present study, even though a small one, sheds some light on the causative agents of bacterial meningitis in Nepalese children. More researches with bigger sample sizes could build on this little base of information.

\section{ACKNOWLEDGEMENT}

The authors express their gratitude to the Research Team, comprising of individuals from Patan Hospital, Oxford University and the New Zealand University, for giving access to the data. Thanks also go to the residents and interns of the children ward of Patan Hospital who helped in recording and organization of these data.

\section{REFERENCES}

1. Keith M, Mary AJ. Meningitis. Pediatrics in Review. 2008; 29:417-429.

2. Williams EJ, Thorson S, Maskey M, Mahat S, Hamaluba M, Dongol S, et al. Hospital-based surveillance of invasive Pneumococcal disease among young children in urban Nepal. Cl Infect Dis. 2009; 48:S11422.

3. Kanegaye, JT, Soliemanzadeh, P, Bradley, JS. Lumbar puncture in pediatric bacterial meningitis: defining the time interval for recovery of cerebrospinal fluid pathogens after parenteral antibiotic pretreatment. Pediatrics 2001; 108:1169.

4. Nigrovic LE, Kuppermann N, Malley R. Children with bacterial meningitis presenting to the emergency department during the Pneumococcal conjugate vaccine era. Acad Emerg Med. 2008; 15(6):522-8.

5. van de Beek D, de Gans J, Spanjaard L, Weisfelt M, Reitsma JB, Vermeulen $\mathrm{M}$. Clinical features and prognostic factors in adults with bacterial meningitis. N Engl J Med. 2004; 351(18):1849-59.

6. Kaplan SL, Mason EO Jr, Wald ER, Schutze GE, Bradley JS, Tan TQ, et al. Decrease of invasive pneumococcal infections in children among 8 children's hospitals in the United States after the introduction of the 7-valent pneumococcal conjugate vaccine. Pediatrics 2004;113:4439.

7. Wenger JD, Hightower AW, Facklam RR, Gaventa S, Broome CV. Bacterial meningitis in the United States, 1986: report of a multistate surveillance study. The Bacterial Meningitis Study Group. J Infect Dis 1990;162(6):1316-23.

8. Nepal 2009 EPI factsheet. World Health Organization. SEARO. IVD. 2010.

9. Talan DA, Hoffman JR, Yoshikawa TT, Overturf GD. Role of empiric parenteral antibiotics prior to lumbar puncture in suspected bacterial meningitis: state of the art. Rev Infect Dis 1988;10 (2):365-76.

10. Schuchat A, Robinson K, Wenger JD, Harrison LH, Farley M, Reingold AL, et al. Bacterial meningitis in the United States in 1995. Active Surveillance Team. N Engl J Med 1997;337 (14):970-6.
11. Susan EC, Robert SD. Haemophilus Influenzae. In: Nelson Textbook of Pediatrics, $18^{\text {th }}$ edition. Behrman RE, Kliegman RM, Jenson HB, Stanton BF (Editors), W. B. Saunders Company, Philadelpia, 2008; p. 1173-74.

12. Feigin, RD, Cutrer,WB. Bacterial meningitis beyond the neonatal period. In: Textbook of Pediatric Infectious Diseases, 6th edition, Feigin, RD, Cherry, JD, Demmler-Harrison, GJ, Kaplan SL (Editors), W. B. Saunders Company, Philadelphia, 2009; p.439.

13. Jon SA, Gary DO. Streptococcus pneumoniae (Pneumococcus). In: Nelson Textbook of Pediatrics, $18^{\text {th }}$ edition. Behrman RE, Kliegman RM, Jenson HB, Stanton BF (Editors), W. B. Saunders Company, Philadelpia, 2008; p. 1133.

14. Karki S, Rai GK, Manadhar R. Bacteriological analysis and sensitivity pattern of blood culture isolates in Kanti Children Hospital. J Nepal Pediatr Soc. 2010; 30:94-97.

15. Arditi, M, Herold, BC, Yogev, R. Cefuroxime treatment failure and Haemophilus influenzae meningitis: case report and review of literature. Pediatrics 1989; 84:132.

16. Klein, J, Feigin, RD, McCracken, GH Jr. Report of the task force on the diagnosis and management of meningitis. Pediatrics 1986; 78:959.

17. Arditi M, Mason EO Jr, Bradley JS, Tan TQ, Barson WJ, Schutze GE, et al. Three-year multicenter surveillance of pneumococcal meningitis in children: clinical characteristics, and outcome related to penicillin susceptibility and dexamethasone use. Pediatrics 1998; 102:1087-97.

18. Lin TY, Nelson JD, McCracken GH Jr. Fever during treatment for bacterial meningitis. Pediatr Infect Dis. 1984; 3(4):319-22.

19. Tunkel, AR, Hartman, BJ, Kaplan, SL, et al. Practice guidelines for the management of bacterial meningitis. Clin Infect Dis 2004; 39:1267.

20. Baraff LJ, Lee SI, Schriger DL. Outcomes of bacterial meningitis in children: a meta-analysis. Pediatr Infect Dis J 1993; 12:389. 